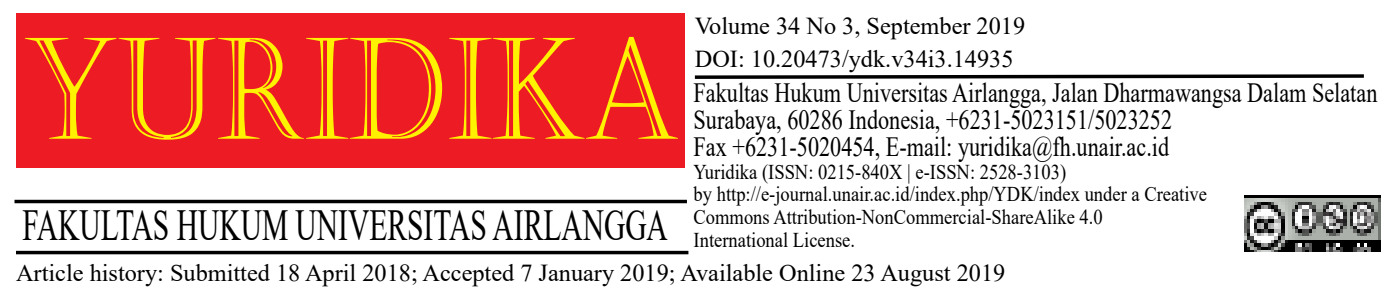

\title{
International Sustainability Self-Regulatory CSR Certification Standards and the Challenges of Embedding Them in the RMG Production Processes in Bangladesh
}

\author{
Md. Ashadujjaman* \\ ashadtex@gmail.com \\ Dhaka University of Engineering and Technology
}

\begin{abstract}
Since the Rana Plaza tragedy in 2013, the Ready-Made Garment (RMG) industry, the most vital role-playing sector in the Bangladeshi economy, has faced many challenges, including labour unrest, image crisis, and pressure from local and international stakeholders to ensure worker safety. The tragic incident in 2013 prompted many initiatives for rehabilitation, the amendment of labour laws, the agreement on treaties for factory inspection, etc. As a consequence, national and international compliance bodies were set up to ensure a safe working environment in the RMG production sector in Bangladesh, such as The Accord, The Alliance, WRAP, BSCI, FLA, ETI, SAI, Sedex, etc. Furthermore, most advanced factories adopted their sustainability self-regulatory sets of norms to ensure a better working environment. Although these local and international compliance initiatives triggered notable changes in the sector, to the working environment and the worker safety, in particular, a major challenge arose for the producing factories to simultaneously comply with all the codes of conducts of the different compliance bodies. This study will present an overview of the most common practices required by the different codes of conducts in the Bangladeshi RMG sector and demonstrate how the different standardization organizations challenge the overall compliance in the RMG production processes in Bangladesh. An analysis of these challenges will also be given, finally leading to a list of eight key points that need to be solved by the producers to deal with the current problems in the industry.
\end{abstract}

Keywords: Self-Regulatory CSR Certification; RMG Production; CSR implementation.

\section{Introduction}

The Ready-Made Garment (RMG) industry in Bangladesh started in 1980

*Lecturer, Department of Textile Engineering, Dhaka University of Engineering and Technology (DUET), Gazipur, Bangladesh (presently). Former Lecturer, Department of Apparel Manufacture and Technology, BGMEA University of Fashion and Technology (BUFT), Dhaka, Bangladesh (2016-2017). 
with the establishment of Desh Garments Ltd. ${ }^{1}$ Since the Bangladeshi garment industry did not need to look behind. Despite the many difficulties faced by the sector over the past years, it has succeeded in creating a niche market and continues to manifest a robust performance. Presently, the Bangladeshi RMG sector export about US\$ 28.15 billion per year; with 4 million people directly depending on the sector and 81 per cent of the country's total export earnings coming from this textile sector. ${ }^{2}$ Despite its positive contributions to the country's economy and global trade, the RMG sector in Bangladesh has faced some serious challenges in recent years, including labour unrest, gas crisis, and a global image crisis. All these problems occurred after the collapse of the Rana Plaza factory, as this tragic incident prompted responses from national and international stakeholders.

The consequent initiatives ranged from mitigation measures such as the rehabilitation and re-integration of survivors to the amendment of labour laws and agreements concerning factory inspections. A coordinated compensation mechanism and a comprehensive factory inspection system were also installed, causing structural changes to the sector. ${ }^{3}$ Ever since the Rana Plaza factory collapsed, it has been a perilous journey for Bangladesh's RMG sector to improve safety standards, ensure workplace safety, and restore the buyers' confidence. The RMG factories were urged to comply with international CSR certification standards to restore the western buyer's faith. Furthermore, international inspection and certification bodies such as The Accord, The Alliance, WRAP, BSCI, ETI, FLA, and Sedex emerged in the period following the catastrophe, prompting remarkable changes to the working environment and worker safety in the RMG sector of Bangladesh. According to The Alliance for Bangladesh Worker Safety (The Alliance)-a legally binding five-year commitment to improve safety in Bangladesh's RMG factories- 85 per cent of all

\footnotetext{
1 BGMEA B2B, 'About Garment Industry of Bangladesh' (Bgmea.com.bd, 2018) <http:// www.bgmea.com.bd/home/about/AboutGarmentsIndustry> accessed 6 March 2018.

2 BGMEA B2B, 'Trade Information' (Bgmea.com.bd, 2018) <http://www.bgmea.com.bd/ home/pages/TradeInformation> accessed 6 March 2018.

3 Today T, 'An Overview Of Bangladesh RMG 2016' (Textile News, Apparel News, RMG News, Fashion Trends, 2018) <https://textiletoday.com.bd/overview-bangladesh-rmg-2016> accessed 6 March 2018.
} 
required factory repairs have now been completed and 80 per cent of high-priority repairs have been made, while the overall remediation has progressed by 80 per cent in RMG factories under The Bangladesh Accord on Fire and Building Safety (The Accord) inspection. ${ }^{4}$

Moreover, RMG factories are going ahead with the implementation of more environmentally friendly processes. Currently, the top three performing environment-friendly LEED-certified garment and textile factories in the world are located in Bangladesh. ${ }^{5}$ Nevertheless, after all these positive outcomes, the producing factories still face major challenges in complying with multiple codes of conducts simultaneously and coordinating with so many compliance bodies for different buyer's requirements. This study will reflect on the international sustainability of self-regulatory CSR certification standards and the challenges of embedding them in the RMG production processes in Bangladesh.

For this research, the main focus point will be the challenges faced by producers in order to comply with international sustainability self-regulatory CSR certification norms. The Bangladeshi producers' perception on the applicability of these self-regulatory CSR norms was sourced through primary and secondary data collection. Primary data collection, to identify the core challenges faced to embed these self-regulatory CSR norms, interviews were conducted with the top-management of five giant garment manufacturing groups, i.e. EPYLLION Group, VIYELLATEX Group, Envoy Group, Northern Trifa Group, SIMCO Group, and a specialised newspaper devoted to the RMG sector of Bangladesh, The Bangladesh Textile Today. These interviews were selected according to the person's compliance with the self-regulatory CSR certification norms. An openend questionnaire method was followed, highlighting their current status of self-

4 CPD RMG Study, 'Bangladesh Made Progress in Workplace Safety and Compliance in 2017' (CPD RMG Study, 2018) <http://rmg-study.cpd.org.bd/bangladesh-made-progress-workplace-safety-compliance-2017/> accessed 6 March 2018.

5 Textile Today, 'How Green Are the "Green Factories"?' (Textile News, Apparel News, RMG News, Fashion Trends, 2018) <https://textiletoday.com.bd/green-green-factories/> accessed 6 March 2018. 
regulatory CSR certification norms and asking about the challenges faced while complying with these norms.

Secondary data collection, data was collected mainly from the corresponding official websites, newsletters, magazines, reports, and bulletins; to identify the current status of CSR implementation and the specific CSR codes of conducts of the international certification bodies working to ensure CSR compliance in the RMG sector of Bangladesh.

\section{Overview of the Selected CSR Certification Bodies}

For the interviews, the most common CSR certification bodies in factories were selected, they include:

1. The Accord on Fire and Building Safety in Bangladesh (The Accord): This is a fiveyear legally binding independent agreement concluded between multiple global brands, retailers, and Bangladeshi trade unions, designed to build a safe and healthy Bangladeshi RMG Industry. It represents the majority of EU importers of RMG from Bangladesh. The Accord conducts independent inspections on fire and electrical and structural safety following The Accord Building Standards based on the Bangladesh National Building Code (BNBC). Contracted international engineering firms conduct these inspections. The Accord is involved with over 1600 factories in Bangladesh, and their overall remediation progress is at 79 per cent. ${ }^{6}$

2. The Alliance for Bangladesh Worker Safety (The Alliance): The Alliance is a legally binding five-year commitment involving apparel industries and stakeholders, including the USA and Bangladeshi governments, policymakers, NGOs, members of civil society, and organised labour, to improve worker safety in Bangladeshi RMG factories. It represents the majority of North American importers. The Alliance conducts individual and shared inspections with The Accord on Fire, Electrical and Structural Safety, following the shared Fire Safety

\footnotetext{
6 Accord On Fire And Building Safety in Bangladesh, 'The Bangladesh Accord On Fire And Building Safety' (The Bangladesh Accord, 2018) <http://bangladeshaccord.org> accessed 6 March 2018.
} 
and Structural Integrity Standard. The inspection is conducted by independent Qualified Assessment Firms. The Alliance is engaged with over 600 factories in Bangladesh and among these factories, Non-Compliant Completion is at 83.9 per cent, and Non-Compliant Completion in progress is at 15.8 per cent. $^{7}$

3. Worldwide Responsible Accredited Production (WRAP): WRAP is an independent and objective body, which helps apparel and footwear factories around the world verify that they are operating in compliance with local laws and internationally-accepted standards of ethical workplace practices. There are currently 2,395 WRAP-certified facilities around the world and 254 factories in Bangladesh. WRAP adheres to the following codes of conduct: Compliance with Laws and Workplace Regulations, Prohibition of Forced Labour, Prohibition of Child Labour, Prohibition of Harassment or Abuse, Fair Compensation and Benefits, Decent hours of Work, Prohibition of Discrimination, Health and Safety, Freedom of Association and Collective Bargaining, Safety of Environment, Customs Compliance, and Security issues. ${ }^{8}$

4. The Business Social Compliance Initiative (BSCI): BSCI is a leading supply chain management system that supports companies to drive social compliance and improvements within the factories and farms in their global supply chains. BSCI implements the core international labour standards protecting workers' rights, such as the ILO conventions and declarations. BCSI adheres to the following codes of conduct: The Rights of Freedom of Association and Collective Bargaining, Fair Remuneration, Occupational Health and Safety, Special Protection for Young Workers, No Bonded Labour, Ethical Business Behaviour, No Discrimination, Decent Working Hours, No Child Labour, No Precarious Employment, and Protection of the Environment. ${ }^{9}$

\footnotetext{
7 Alliance For Bangladesh Worker Safety, 'The Alliance for Bangladesh Worker Safety Has Ceased Operations as Planned on December 31, 2018' (Bangladeshworkersafety.org, 2018) <http:// www.bangladeshworkersafety.org> accessed 6 March 2018.

8 Wrapcompliance.org, 'Worldwide Responsible Accredited Production (WRAP), 'Social Compliance Certification Organization For The Garment Industry Garment Fire Safety' (Wrapcompliance.org, 2018) <http://www.wrapcompliance.org> accessed 6 March 2018.

9 Social Accountability Accreditation services, 'Business Social Compliance Initiative (BSCI)' (Social Accountability Accreditation services, 2018) < http://www.saasaccreditation.org/ bsci> accessed 6 March 2018.
} 
5. Ethical Trading Initiative (ETI): ETI is a leading alliance of companies, trade unions, and NGOs that promotes respect for workers' rights around the globe. Their vision is to build a world, where all workers are free from exploitation and discrimination, and enjoy conditions of freedom, security, and equity. ETI adheres to the following codes of conduct: Employment is freely chosen, Freedom of association, Working conditions are safe and hygienic, Child labour shall not be used, Living wages are paid, Working hours are not excessive, No discrimination is practiced, Regular employment is provided, and No harsh or inhumane treatment is allowed. ${ }^{10}$

6. The Social Accountability International (SAI): The SAI is a global non-governmental organization advancing human rights at work by teaming up with a diverse group of stakeholders including brands, suppliers, governments, trade unions, non-profits, and academia. SAI empowers workers and managers at all levels of the supply chain by using its multi-industry SA8000® Standard. SAI adheres to the following code of conducts: No Child Labour, No Forced or Compulsory Labour, Ensuring Health and Safety, Freedom of Association, No Discrimination, Disciplinary Practices, No additional Work Hour, Fair Remuneration, and Management System. ${ }^{11}$

7. The Supplier Ethical Data Exchange (Sedex): Sedex is the world's largest collaborative data sharing platform for responsible sourcing in supply chains, used by more than 43,000 members in over 150 countries. Tens of thousands of companies use Sedex to ensure labour rights, health \& safety, the environment, and business ethics. SMETA (Sedex Members Ethical Trade Audit) is the audit methodology made by Sedex, which uses the Ethical Trading Initiative (ETI) Base Code and the local law as its monitoring standards. ${ }^{12}$

${ }^{10}$ Ethical Trading Initiative, 'For More than 20 Years, ETI and Our Members Have Been a Driving Force in Ethical Trade' (Ethicaltrade.org, 2018) <https://www.ethicaltrade.org> accessed 6 March 2018.

11 Social Accountability International, 'Social Accountability International' (Sa-intl.org, 2018) <http://www.sa-intl.org> accessed 6 March 2018.

12 Sedex, 'Empowering Responsible Supply Chains' (Sedex, 2018) <https://www.sedexglobal.com> accessed 6 March 2018. 


\section{Results and Discussion}

The eight key challenges for the producers to comply with buyers' compliance are as follows:

\begin{tabular}{|c|c|c|}
\hline Key Challenges & Problems Associated with Producers & Possible Solutions \\
\hline No unification & $\begin{array}{l}\text { - Different buyers follow different } \\
\text { compliance certifications } \\
\text { - Each producer supplies many buyers }\end{array}$ & $\begin{array}{l}\text { - A common platform like } \\
\text { 'The Accord' or 'The Alli- } \\
\text { ance' could be used by all } \\
\text { buyers to create a single } \\
\text { Code of Conduct }\end{array}$ \\
\hline $\begin{array}{l}\text { Additional work } \\
\text { hours }\end{array}$ & $\begin{array}{l}\text { - Fast fashion } \\
\text { - Interruption of gas and electricity } \\
\text { supply } \\
\text { - Delay in port clearance }\end{array}$ & $\begin{array}{l}\text { - Early dispatch of design } \\
\text { - Flexibility in delivery date } \\
\text { - Specialised port for RMG }\end{array}$ \\
\hline $\begin{array}{l}\text { Payment issues for } \\
\text { compliance }\end{array}$ & $\begin{array}{l}\text { - Ensuring compliance requires a high } \\
\text { price } \\
\text { - Buyers continue to decrease RMG } \\
\text { prices } \\
\text { - Fast fashion }\end{array}$ & $\begin{array}{l}\text { - Compliance should be con- } \\
\text { verted into business cases } \\
\text { with specified price }\end{array}$ \\
\hline $\begin{array}{l}\text { Freedom of } \\
\text { association }\end{array}$ & $\begin{array}{l}\text { - Worker unions leaders are corrupt } \\
\text { - Politically biased leaders } \\
\text { - Large governmental factories have } \\
\text { already closed }\end{array}$ & $\begin{array}{l}\text { - Our Worker Participation } \\
\text { Committee (WPC) might be } \\
\text { an alternative role model for } \\
\text { the world }\end{array}$ \\
\hline Living wages & $\begin{array}{l}\text { - Producers commission is small } \\
\text { - Business itself isn't sustainable } \\
\text { - Fast fashion }\end{array}$ & $\begin{array}{l}\text { - More cents for workers } \\
\text { - A good system of gover- } \\
\text { nance } \\
\text { - Sustainable consumption }\end{array}$ \\
\hline $\begin{array}{l}\text { Environmental } \\
\text { emissions }\end{array}$ & $\begin{array}{l}\text { - ETP requires high investment } \\
\text { - Difficult for small entrepreneurs } \\
\text { - No strict observations }\end{array}$ & $\begin{array}{l}\text { - Financial help for small to } \\
\text { medium entrepreneurs } \\
\text { - A good and strict observa- } \\
\text { tion system }\end{array}$ \\
\hline $\begin{array}{l}\text { Why only } \\
\text { Bangladesh? }\end{array}$ & $\begin{array}{l}\text { - Buyers are only forcing compliance } \\
\text { in Bangladesh } \\
\text { - No mandatory compliance for other } \\
\text { competitor countries }\end{array}$ & $\begin{array}{l}\text { - Compliance policy should } \\
\text { be the same for all manufac- } \\
\text { turing countries }\end{array}$ \\
\hline $\begin{array}{l}\text { Monetary value of } \\
\text { water }\end{array}$ & $\begin{array}{l}\text { - To process one kilogramme of gar- } \\
\text { ments from cotton fibres (excluding } \\
\text { water required for cotton growing) } \\
\text { takes about } 70-80 \text { litres of water. } \\
\text { - Buyers do not pay for the water }\end{array}$ & $\begin{array}{l}\text { - An exact estimation of cost } \\
\text { is needed for every single } \\
\text { resource spent }\end{array}$ \\
\hline
\end{tabular}

Source: Author' Result 
The issues mentioned above are the vital challenges currently faced by the RMG sector of Bangladesh. In order to resolve all these issues, every stakeholder should see it as their responsibility to come forward and contribute. The implementation of best practices of CSR not only improves the working condition but also improves the quality of the product. Although some challenges like trade unions are difficult to overcome due to the overall demographic business environment, an alternative manner like the formation of Worker Participation Committee (WPC) can assist in overcoming them. Furthermore, financial assistance from stakeholders will be needed to resolve all these issues. As infrastructural issues act as a hindrance to the successful implementation of self-regulatory CSR norms, further problems such as additional work hours may arise. Finally, the manufacturing assembly should be careful regarding its resources, especially natural resources such as water, to achieve sustainable production.

\section{Conclusion}

The norms of different CSR certification bodies followed in the RMG industry in Bangladesh have been extensively reviewed in this article. Based on the fieldwork on Bangladeshi RMG industries, eight major challenges have arisen due to the compliance with norms of multiple CSR certifications. The probable causes for these problems have been given, as well as solutions to overcome them. Additionally, the issues related to these major challenges have been discussed. Among these challenges, the unification of the CSR certification appears as one of the crucial solutions in this study. Another significant factor in this situation is the mandatory implementation of CSR certification only in Bangladesh, in contrast to competitor garment sourcing countries, i.e., China, India, Pakistan, Vietnam, etc. Furthermore, the lack of willingness of international buyers to pay extra for products that are manufactured in compliance with the international CSR standards constitutes another significant economic factor. Besides, environmental emissions, price of water, freedom of association, living wages, and additional work hour issues are also imposing huge threat for the growth of garment sector in Bangladesh 
and needed urgent concern from the stakeholders.

\section{Bibliography}

Accord On Fire And Building Safety in Bangladesh, 'The Bangladesh Accord On Fire And Building Safety' (The Bangladesh Accord, 2018) < http:// bangladeshaccord.org> accessed 6 March 2018.

Alliance For Bangladesh Worker Safety, 'The Alliance for Bangladesh Worker Safety Has Ceased Operations as Planned on December 31, 2018' (Bangladeshworkersafety.org, 2018) <http://www.bangladeshworkersafety. org> accessed 6 March 2018.

BGMEA B2B, 'About Garment Industry of Bangladesh' (Bgmea.com.bd, 2018) $<$ http://www.bgmea.com.bd/home/about/AboutGarmentsIndustry $>$ accessed 6 March 2018.

—, 'Trade Information' (Bgmea.com.bd, 2018) <http://www.bgmea.com.bd/ home/pages/TradeInformation> accessed 6 March 2018.

CPD RMG Study, 'Bangladesh Made Progress in Workplace Safety and Compliance in 2017' (CPD RMG Study, 2018) <http://rmg-study.cpd.org.bd/bangladeshmade-progress-workplace-safety-compliance-2017/> accessed 6 March 2018.

Ethical Trading Initiative, 'For More than 20 Years, ETI and Our Members Have Been a Driving Force in Ethical Trade' (Ethicaltrade.org, 2018) <https:// www.ethicaltrade.org> accessed 6 March 2018.

Sedex, 'Empowering Responsible Supply Chains' (Sedex, 2018) <https://www. sedexglobal.com> accessed 6 March 2018.

Social Accountability Accreditation services, 'Business Social Compliance Initiative (BSCI)' (Social Accountability Accreditation services, 2018) < http://www. saasaccreditation.org/bsci> accessed 6 March 2018.

Social Accountability International, 'Social Accountability International' (Sa-intl. org, 2018) <http://www.sa-intl.org> accessed 6 March 2018.

Textile Today, 'How Green Are the “Green Factories"?' (Textile News, Apparel News, RMG News, Fashion Trends, 2018) <https://textiletoday.com.bd/ green-green-factories/> accessed 6 March 2018.

Today T, 'An Overview Of Bangladesh RMG 2016' (Textile News, Apparel News, RMG News, Fashion Trends, 2018) <https://textiletoday.com.bd/overviewbangladesh-rmg-2016> accessed 6 March 2018. 
Wrapcompliance.org, 'Worldwide Responsible Accredited Production (WRAP), 'Social Compliance Certification Organization For The Garment Industry Garment Fire Safety' (Wrapcompliance.org, 2018) <http://www. wrapcompliance.org> accessed 6 March 2018.

HOW TO CITE: Md. Ashadujjaman, 'International Sustainability Self-Regulatory CSR Certification Standards and the Challenges of Embedding Them in the RMG Production Processes in Bangladesh' (2019) 34 Yuridika. 